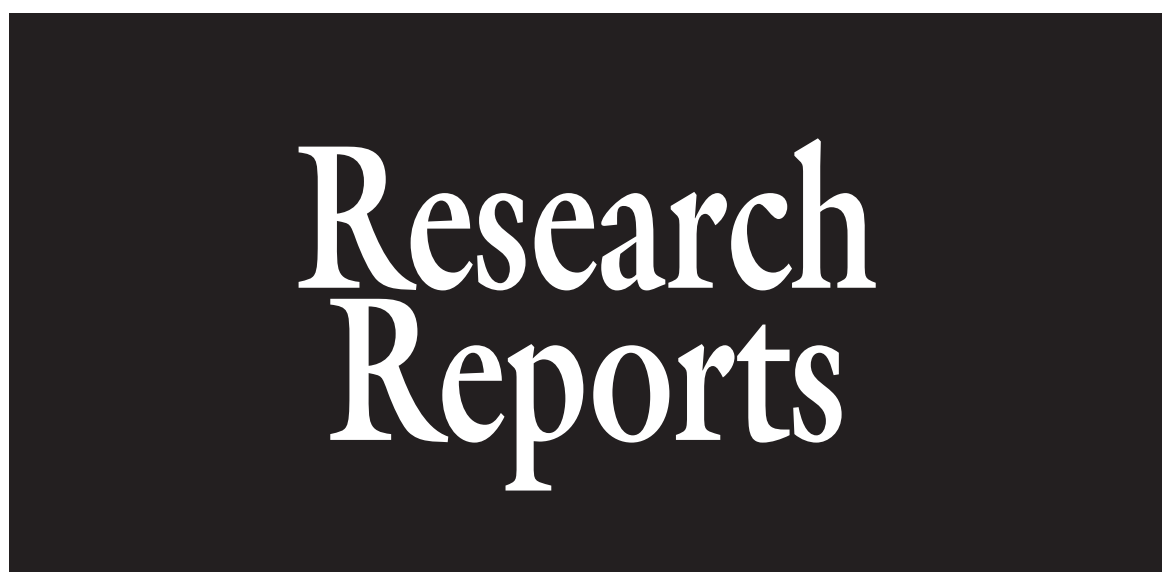

\section{Influence of Shoot Pruning on Bacterial Spot Infestation on Tomato Cultivars}

\author{
Gary E. Vallad and Bielinski M. Santos ${ }^{1}$
}

AdDitional INDEX wORDs. Lycopersicum esculentum, cultural practices, disease management, fungicides, bactericides, production costs

Summary. Field studies were conducted in Florida to determine the effect of early shoot pruning on the severity of bacterial spot, and on the growth and yield of different tomato (Solanum lycopersicum) cultivars. Two tomato cultivars, two inoculation regimes of bacterial spot pathogen (Xanthomonas perforans), and three shoot pruning programs were arranged in a split-split plot design. The tomato cultivars were Tygress and Security-28; shoot pruning included none, light, and heavy; and $X$. perforans treatments consisted of non-inoculated plots and plots inoculated with a suspension of the pathogen. Tomato plant height was not influenced by any of the three factors or their interactions, whereas the disease severity was higher in inoculated plots versus non-inoculated plants. Early extralarge fruit weight was affected by tomato cultivars and the inoculation with the bacterial spot pathogen, but not by pruning programs or the interaction among factors. Tomato plants inoculated with $X$. perforans reduced their extra-large fruit weight by $31 \%$ in comparison with non-inoculated plants. There were no differences on early marketable fruit weight among the combinations of each cultivar and the three pruning programs. All three factors individually influenced the seasonal marketable fruit weight of tomato, with no difference between light-pruned plants and the non-pruned control for seasonal marketable fruit weight, regardless of tomato cultivars. However, heavy pruning did reduce seasonal yields by $10 \%$ in comparison with the non-pruned control. These results indicated that light shoot pruning, which is the standard grower practice in Florida, did not improve bacterial spot control or tomato yields of total and extra-large marketable fruit, which might save up to $\$ 50 /$ acre in reduced labor costs for Florida tomato growers.

I n the United States, $\approx 105,700$ acres were planted with tomatoes in 2009 , grossing $\$ 1.31$ billion in sales [U.S. Department of Agriculture (USDA), 2010]. Production in Florida and California covers two-thirds of the total area in the country planted in tomato. Florida accounted for nearly $40 \%$ of the total U.S. gross sales (USDA, 2010). Among the many

Gulf Coast Research and Education Center, IFAS, University of Florida, 14625 CR 672, Wimauma, FL 33598

${ }^{1}$ Corresponding author. E-mail: bmsantos@ufl.edu. diseases that affect tomato, bacterial spot is one of the most troublesome (Bouzar et al., 1999; Jones et al., 2004;
O'Garro and Charlemagne, 1994; O'Garro and Tudor, 1994; Pernezny et al., 1996; Pohronezny and Volin, 1983). This disease is caused by various Xanthomonas species [X. perforans, $X$. vesicatoria, $X$. euvesicatoria, and $X$. gardneri (formerly referred to as $X$. campestris pv. vesicatoria)] and is favored by warm, humid weather, but is often initiated by episodes of winddriven rain. On the leaves, infection begins when the bacterium enters the plant through natural openings and wounds, where it multiplies within plant tissues. Within 3 to $4 \mathrm{~d}$, the first symptoms of water-soaked lesions can be observed on lower leaf surfaces. If ideal environmental conditions persist, lesions can enlarge and coalesce, causing extensive leaf chlorosis and defoliation. Once established, the disease can still cause significant losses, even in the absence of rain. Under conditions of high relative humidity such as a heavy dew or fog, the disease can spread around the leaf margin by the infection of hydathodes and can cause a general blighting that can again lead to premature leaf drop even when only moderate disease pressure exists. All aboveground tissues are susceptible to the disease. Fruit lesions begin as small raised blisters on the fruit surface that are a lighter green than the rest of the immature fruit. As the lesions enlarge, they turn brown to black and develop a layer of scab-like tissue (Jones, 1991). Fruit lesions are particularly problematic for growers because they not only affect fruit appearance, but also offer a site for other microbes to enter the fruit.

Control of bacterial spot relies on cultural exclusion of the pathogen from production areas, the use of resistant cultivars, and diligent application of copper-based bactericides. Regardless of control attempts, bacterial spot epidemics occur every season in most tomato production regions. The presence of infected tomato

\begin{tabular}{llll}
\hline $\begin{array}{l}\text { Units } \\
\begin{array}{l}\text { To convert U.S. to SI, } \\
\text { multiply by }\end{array}\end{array}$ & U.S. unit & SI unit & $\begin{array}{l}\text { To convert SI to U.S., } \\
\text { multiply by }\end{array}$ \\
\hline 0.4047 & $\mathrm{acre}(\mathrm{s})$ & $\mathrm{ha}$ & 2.4711 \\
29.5735 & $\mathrm{fl} \mathrm{oz}$ & $\mathrm{mL}$ & 0.0338 \\
0.3048 & $\mathrm{ft}$ & $\mathrm{m}$ & 3.2808 \\
3.7854 & $\mathrm{gal}$ & $\mathrm{L}$ & 0.2642 \\
2.54 & inch $(\mathrm{es})$ & $\mathrm{cm}$ & 0.3937 \\
1.1209 & $\mathrm{lb} / \mathrm{acre}$ & $\mathrm{kg} \cdot \mathrm{ha}^{-1}$ & 0.8922 \\
0.0254 & $\mathrm{mil}$ & $\mathrm{mm}$ & 39.3701 \\
2.2417 & ton/acre & $\mathrm{Mg} \cdot \mathrm{ha}^{-1}$ & 0.4461 \\
$\left({ }^{\circ} \mathrm{F}-32\right) \div 1.8$ & ${ }^{\circ} \mathrm{F}$ & ${ }^{\circ} \mathrm{C}$ & $\left(1.8 \times{ }^{\circ} \mathrm{C}\right)+32$
\end{tabular}


volunteers and weedy hosts are common sources of local inoculum. Infected seed and transplants not only act as inoculum sources, but they are also a mode of long-distance movement and disease spread. The use of copper-based bactericides can offer some level of control, except under the most extreme weather conditions. However, the reliance on copper in agriculture has led to widespread copper tolerance among bacterial pathogens on many crops. A dithiocarbamate (maneb or mancozeb) is routinely combined with copper-based bactericides to enhance bacterial spot control (Conover and Gerhold, 1981; Jones et al., 1991), but this reduces the fungicidal activity of the dithiocarbamate (Jones and Jones, 1985). The overuse of copper-based pesticides in vegetable production can adversely affect crop growth and the environment (Arnold et al., 2004; Hushon, 2006; Pietrzak and McPhail, 2004; Rhoads et al., 1989; Rice et al., 2002). Although successful under experimental settings, the integrated use of bacteriophages (Jones et al., 2007; Obradovic et al., 2004, 2005) and the use of plant defense elicitors (Louws et al., 2001; Roberts et al., 2008) have found only limited success under commercial conditions. Therefore, there is a need for additional practices to manage bacterial spot.

Most growers of round tomatoes in Florida and California perform shoot pruning on their crops during the early part of the growing season to reduce the number of unwanted lateral branches. This practice usually occurs between 2 and 4 weeks after transplanting (WAT) by hand-removing shoots from the ground level up to the primary fork below the first flower cluster ("light" pruning). Previous research showed that for some cultivars, shoot pruning is unnecessary (Kemble et al., 1994; Santos, 2008). However, other studies established that shoot pruning increased early yield, but reduced total yield (Carlton et al., 1994; Sikes and Coffey, 1976). Navarrete and Jeannequin (2000) found that when shoot pruning was performed every $21 \mathrm{~d}$, tomato stem diameter, vigor, fruit number, and fruit weight decreased.

It is hypothesized that shoot pruning could be a potential practice to reduce bacterial spot infection because it reduces the amount of foliage near the soil that could serve as an initial point of entry for the bacterium, and it changes the architecture of plant canopies thus changing air and moisture flow through the leaves (Carlton et al., 1994). Additionally, shoot pruning costs about $\$ 50$ /acre in labor based on grower estimations and direct observations of production fields, which is a significant expense for tomato production. The objective of this study was to determine the effect of early shoot pruning on the severity of bacterial spot and on the growth and yield of different tomato cultivars.

\section{Materials and methods}

Two field trials were conducted in the Spring and Fall 2009 at the Gulf Coast Research and Education Center of the University of Florida in Balm, FL, where the soil is classified as a Myakka fine sand siliceous hyperthermic Oxyaquic Alorthod with 1.5\% organic matter and a $\mathrm{pH}$ of 7.3. Planting beds were pre-formed with a standard bedder and were 32 inches wide at the base, 28 inches wide at the top, 8 inches high, and spaced $5 \mathrm{ft}$ apart on centers. Beds were fumigated 3 weeks before transplanting with methyl bromide plus chloropicrin $(67: 33, \mathrm{v} / \mathrm{v})$ at a rate of $175 \mathrm{lb} /$ acre applied through three chisels spaced 12 inches apart, which delivered fumigant 6 inches deep to eliminate soilborne diseases, nematodes, and weeds. Within 1 min after fumigation, a drip irrigation line $(0.45$ $\mathrm{gal} / \mathrm{min}$ per $100 \mathrm{ft}$ of bed; T-Tape Systems International, San Diego) was placed in all plots at a depth of 1 inch in the center of the bed, which was covered with 1-mil-thick silveron-black mulch. This mulch was selected because it allows better regulation of soil temperatures during cool and warm months of the year. Tomato seedlings (Speedling, Sun City, FL) in the four-true-leaf stage ( 8 inches tall) were transplanted in single rows and 2 inches offset of bed centers. Planting during each season occurred on 17 Feb. and 31 Aug. 2009. In-row distance was 18 inches, which resulted in a population density of 5808 plants / acre. Drip irrigation was provided three times per day with irrigation cycles between 15 and 45 min (after a 10 -min of line pressurization), depending on the crop growth stage.

Twelve treatments resulted from the combination of two tomato cultivars, two bacterial spot inoculation regimes, and three shoot pruning programs. The tomato cultivars were Tygress and Security-28, which are resistant to the tomato yellow leaf curl virus. Shoot pruning levels were none, light, and heavy. Light pruning was defined as carefully removing by hand only two to three lateral buds ("suckers") from the main stems from ground level to 6 inches high, whereas heavy pruning was defined as the hand removal of all the lateral buds and stems up to 6 inches high. Early shoot pruning occurred between 3 and 4 WAT. Inoculation with the bacterial spot pathogen consisted of non-inoculated plots and plots inoculated with a suspension of $X$. perforans strain XT4 $\left(1 \times 10^{6} \mathrm{cfu} /\right.$ $\mathrm{mL}$ ), which was applied to the foliage with a conventional backpack sprayer at 5 WAT at a volume of $\approx 15 \mathrm{~mL}$ per plant.

The treatments were arranged in a split-split plot design with five replications, where the tomato cultivars were in the main plots, inoculation with the bacterial spot pathogen in the subplots, and shoot pruning regimes in the sub-subplots. Experimental units were $20 \mathrm{ft}$ long (10 tomato plants/plot) with a 5-ft-long in-row non-treated buffer zone between experimental units. Current recommendations for insect and disease control were followed and plant nutrients were injected using the linear bed-foot system at recommended sufficiency levels and according to current nutritional recommendations (Olson et al., 2006). Each trial was 12 weeks from the time of transplanting to the last harvest, during which the crop was staked at 3 WAT and tied three times at $\approx 3,5$, and 8 WAT. Average, minimum, and maximum temperatures were 66,33 , and $89^{\circ} \mathrm{F}$ during Mar. 2009 , and 80,62 , and $96^{\circ} \mathrm{F}$ during Sept. 2009. Rainfall averages during those months were 1.2 and 5.5 inches, respectively.

Plant heights were determined at 3 and 6 WAT by measuring the vertical distance between bed tops and the highest opened growing point. Tomato fruit were harvested twice (10 and 12 WAT) in the mature green stage and were graded following current market standards as extra-large and marketable fruit of all categories (Sargent et al., 2005). Fruit yield from the first harvest (10 WAT) were considered early fruit weight, while the summation of two harvests (10 and 12 WAT) was 
the seasonal fruit weight. For bacterial spot, plots were monitored for disease and were rated for severity at 7 and 9 WAT in the spring trial, and at 9 and 11 WAT in the fall trial using the HorsfallBarratt scale, a non-dimensional, 12point scale, to assess the percentage of canopy affected by bacterial leaf spot (Horsfall and Barratt, 1945). Disease severity values were converted to midpercentages and were used to generate area under disease progress curve (AUDPC) using the trapezoidal method before statistical analyses (Jeger, 2004). Data were subjected to analysis of variance to determine significance $(P<0.05)$ of main effects and their interactions on the variables [Statistix, version 7 (Analytical Software, Tallahassee, FL) and SAS, version 9.1 (SAS Institute, Cary, NC)]. Significant treatment means were separated using Fisher's protected least significant difference (LSD) test at the $5 \%$ level.

\section{Results and discussion}

There were no significant season by treatment interactions for tomato plant height at 3 and 6 WAT, disease severity, and early and seasonal fruit weights. Therefore, data from these variables for both seasons were combined for analysis. Tomato plant height at 3 and 6 WAT was not influenced by any of the three factors under study or their interactions (Table 1). Thus, tomato plants were the same heights averaging $32.0 \mathrm{~cm}$ when shoot pruning was performed ( $3 \mathrm{WAT})$, and shoot pruning did not affect tomato plant height at 6 WAT, which ranged between 57.1 and $58.8 \mathrm{~cm}$ at 6 WAT, regardless of cultivars and bacterial spot inoculation.

BaCterial SPOT PROGRESS. The effect of $X$. perforans inoculation was significant with disease severity based on AUDPC of 1445 (average disease severity of $41 \%$ ) in inoculated versus an AUDPC of 821 (average disease severity of $29 \%$ ) in non-inoculated plots averaged across both seasons (Table 1). Disease severity was greater at the end of the Spring 2009 trial in comparison with the end of the Fall 2009 trial (65\% and $35 \%$, respectively). Inversely, initial disease severity was much greater in the fall study ( $24 \%$ disease severity in non-inoculated plots) than the spring trial $(1.5 \%$ disease severity in non-inoculated plots). 'Tygress' was more susceptible to inoculation with the bacterial spot pathogen than
'Security-28', exhibiting 20.4\% more disease on average based on AUDPC. There was no interaction between trials and cultivars, and no other interactions were observed among the remaining whole plot and subplot factors.

EARLY FRUIT WEIGHT. Early extra-large fruit weight was affected by tomato cultivar and the inoculation with the bacterial spot pathogen, but not by pruning program or the interaction among factors. 'Security-28' had the highest early extra-large fruit weight with 5.1 tons/acre, which was more than 2.5 times higher than that obtained with 'Tygress' (Table 2). Tomato plants inoculated with $X$. perforans reduced their extra-large fruit

Table 1. Effects of early shoot pruning levels, tomato cultivars, and bacterial spot inoculation on tomato plant height at 3 and 6 weeks after transplanting (WAT) and average area under the disease progress curve (AUDPC) in Spring and Fall 2009 at Balm, FL.

\begin{tabular}{|c|c|c|c|}
\hline & \multicolumn{2}{|c|}{ Plant ht $(\mathrm{cm})^{\mathrm{z}}$} & \multirow[b]{2}{*}{ AUDPC } \\
\hline & $3 \mathrm{WAT}$ & $6 \mathrm{WAT}$ & \\
\hline \multicolumn{4}{|l|}{ Pruning } \\
\hline Non-pruned & 31.3 & 57.1 & 1157 \\
\hline Light & 33.0 & 57.1 & 1091 \\
\hline Heavy & 31.7 & 58.8 & 1150 \\
\hline Significance $(P<0.05)^{\mathrm{x}}$ & NS & NS & NS \\
\hline \multicolumn{4}{|l|}{ Cultivar } \\
\hline 'Security-28' & 32.2 & 57.8 & $1028 b^{x}$ \\
\hline 'Tygress' & 31.8 & 57.5 & 1238 a \\
\hline Significance $(P<0.05)^{\mathrm{x}}$ & NS & NS & * \\
\hline \multicolumn{4}{|l|}{ Bacterial spot } \\
\hline Non-inoculated & 32.5 & 59.3 & $821 \mathrm{~b}$ \\
\hline Inoculated & 31.5 & 56.1 & 1445 a \\
\hline Significance $(P<0.05)^{\mathrm{x}}$ & NS & NS & * \\
\hline
\end{tabular}

${ }^{\mathrm{z}} 1 \mathrm{~cm}=0.3937$ inch

'Disease severity was rated using the Horsfall-Barratt scale, a non-dimensional, 12 -point scale, to assess the percentage of canopy affected by bacterial leaf spot. Values were converted to mid-percentages and used to generate AUDPC.

${ }^{x}$ Column means separated by Fisher's protected least significant difference test $(P<0.05)$. Values followed by the same letter in the same column do not differ at the $5 \%$ significance level. Ns and * $=$ non-significant and significant, respectively.

Table 2. Effects of early shoot pruning levels, tomato cultivars, and bacterial spot inoculation on early extra-large and total marketable fruit weight in Spring and Fall 2009 at Balm, FL.

\begin{tabular}{|c|c|c|c|}
\hline & $\begin{array}{c}\text { Extra-large } \\
\text { fruit wt } \\
\text { (tons } / \text { acre) }^{\mathrm{z}}\end{array}$ & & $\begin{array}{c}\text { Marketable } \\
\text { fruit wt } \\
\text { (tons } / \text { acre })^{z}\end{array}$ \\
\hline Pruning & & Pruning $\times$ cultivar & \\
\hline Non-pruned & 3.5 & $\begin{array}{l}\text { Non-pruned, } \\
\text { 'Security-28' }\end{array}$ & $7.4 \mathrm{a}^{\mathrm{y}}$ \\
\hline Light & 3.6 & Light, 'Security-28' & $7.1 \mathrm{a}$ \\
\hline Heavy & 3.4 & Heavy, 'Security-28' & $6.3 \mathrm{a}$ \\
\hline Significance $(P<0.05)^{\mathrm{y}}$ & NS & Non-pruned, 'Tygress' & $3.4 \mathrm{~b}$ \\
\hline Cultivar & & Light, 'Tygress' & $3.7 \mathrm{~b}$ \\
\hline 'Security-28' & $5.1 \mathrm{a}^{\mathrm{y}}$ & Heavy, 'Tygress' & $4.4 \mathrm{~b}$ \\
\hline 'Tygress’ & $1.9 \mathrm{~b}$ & Significance $(P<0.05)$ & * \\
\hline Significance $(P<0.05)^{\mathrm{y}}$ & * & & \\
\hline Bacterial spot & & Bacterial spot & \\
\hline Non-inoculated & $4.2 \mathrm{a}$ & Non-inoculated & $6.4 \mathrm{a}$ \\
\hline Inoculated & $2.9 \mathrm{~b}$ & Inoculated & $4.8 \mathrm{~b}$ \\
\hline Significance $(P<0.05)$ & * & Significance $(P<0.05)$ & * \\
\hline
\end{tabular}

${ }^{z}$ Extra-large fruit were between 7.3 and $8.8 \mathrm{~cm}$ in equatorial diameter. Marketable fruit were the summation of extra-large, large (between 6.4 and $7.2 \mathrm{~cm}$ ), and medium (between 5.8 and $6.3 \mathrm{~cm}$ ); $1 \mathrm{~cm}=0.3937 \mathrm{inch}, 1$ ton/ acre $=2.2417 \mathrm{Mg} \cdot \mathrm{ha}^{-1}$.

y'Column means separated by Fisher's protected least significant difference test $(P<0.05)$. Values followed by the same letter in the same column do not differ at the $5 \%$ significance level. NS and * $=$ non-significant and significant, respectively. 
weight by $31 \%$ in comparison with those non-inoculated with the bacterium. Pruning programs resulted in extra-large yields ranging between 3.4 and 3.6 tons/acre. Early marketable fruit weight was influenced by the interaction between cultivars and pruning programs, and separately by the inoculation with the bacterial spot pathogen (Table 2). There were no differences on early marketable fruit weight among the combinations of 'Security-28' and the three pruning programs, which averaged 6.9 tons/ acre of fruit. At the same time, all pruning programs in plots planted with 'Tygress' did not differ among each other, while having significantly lower marketable fruit weight at 10 WAT than the 'Security-28' and pruning combinations. Tomato plants in plots inoculated with the bacterial spot pathogen decreased their marketable fruit weight at 10 WAT by $25 \%$ in comparison with non-inoculated plants.

SEAsOnal FRUIT WEIGHT. This variable resulted from the cumulative marketable fruit weight of the two harvests at 10 and 12 WAT. The cultivar by $X$. perforans inoculation interaction affected the seasonal extra-large fruit weight. However, other main factors and interactions were not significant. The highest seasonal extralarge fruit weight was obtained in plots non-inoculated with the bacterial spot

Table 3. Effects of early shoot pruning levels, tomato cultivars, and bacterial spot inoculation on seasonal extra-large and total marketable fruit weight in Spring and Fall 2009 at Balm, FL.

\begin{tabular}{|c|c|c|c|}
\hline & 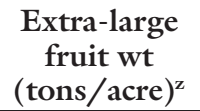 & & $\begin{array}{c}\text { Marketable } \\
\text { fruit wt } \\
\text { (tons/acre) }\end{array}$ \\
\hline \multicolumn{2}{|l|}{ Cultivar $\times$ bacterial spot } & \multicolumn{2}{|l|}{ Pruning } \\
\hline $\begin{array}{l}\text { Non-inoculated, } \\
\text { 'Security-28' }\end{array}$ & $11.1 \mathrm{a}^{\mathrm{y}}$ & Non-pruned & $18.2 \mathrm{a}^{\mathrm{y}}$ \\
\hline Inoculated, 'Security-28' & $8.1 \mathrm{~b}$ & Light & $17.4 \mathrm{ab}$ \\
\hline Non-inoculated, 'Tygress' & $7.0 \mathrm{c}$ & Heavy & $16.3 \mathrm{~b}$ \\
\hline Inoculated, 'Tygress' & $7.5 \mathrm{c}$ & Significance $(P<0.05)$ & * \\
\hline \multirow[t]{3}{*}{ Significance $(P<0.05)^{\mathrm{y}}$} & * & \multicolumn{2}{|l|}{ Cultivar } \\
\hline & & 'Security-28' & $18.3 \mathrm{a}$ \\
\hline & & 'Tygress' & $15.0 \mathrm{~b}$ \\
\hline \multicolumn{2}{|l|}{ Pruning } & Significance $(P<0.05)$ & * \\
\hline Non-pruned & 8.4 & \multicolumn{2}{|l|}{ Bacterial spot } \\
\hline Light & 8.3 & Non-inoculated & $18.1 \mathrm{a}$ \\
\hline Heavy & 8.4 & Inoculated & $15.2 \mathrm{~b}$ \\
\hline Significance $(P<0.05)^{\mathrm{y}}$ & NS & Significance $(P<0.05)$ & * \\
\hline
\end{tabular}

pathogen and planted with 'Security28' (11.1 tons/acre), followed by the combination of 'Security-28' and inoculation with the bacterial spot pathogen (Table 3). There was no effect of the $X$. perforans inoculation on the seasonal extra-large fruit weight obtained in plots planted with 'Tygress'. All three factors individually influenced the seasonal marketable fruit weight of tomato. Non-inoculated plots produced 21\% higher seasonal yields (18.1 tons/acre) in comparison with plants inoculated with bacterial spot (15.2 tons/acre). When comparing pruning programs, there was no difference between light-pruned plants and the nonpruned control for seasonal marketable fruit weight, regardless of tomato cultivar (Table 3). However, heavy pruning did reduce seasonal yields by $10 \%$ in comparison with the non-pruned control.

These results indicate that light shoot pruning, which is the standard grower practice in Florida, did not improve tomato yield of total and extralarge marketable fruit. At the same time, this practice did not reduce the severity of bacterial spot on 'Security28' and 'Tygress' tomato leaves. In contrast, heavy pruning reduced seasonal marketable yields in comparison with non-pruned plants. It is possible that other cultivars may benefit from shoot pruning, as the tested cultivars are newer hybrids introduced to the market for their resistance to tomato yellow leaf curl virus. However, this is unlikely based on previous reports that establish that shoot pruning did not improve tomato fruit yields (Kemble et al., 1994; Santos, 2008). Data also emphasized the impact of bacterial spot on fruit production, especially the production of early extra-large fruit, and the importance of selecting cultivars with improved tolerance to bacterial spot when disease pressure is high. By eliminating light shoot pruning from routine cultural practices, tomato growers can save up to $\$ 50 /$ acre, which might translate into near $\$ 2$ million per year in savings for all the planted areas in Florida.

\section{Literature cited}

Arnold, G.L., M.W. Luckenbach, and M.A. Unger. 2004. Runoff from tomato cultivation in the estuarine environment: Biological effects of farm management practices. J. Exp. Mar. Biol. Ecol. 298: 323-346.

Bouzar, H., J.B. Jones, R.E. Stall, F.J. Louws, M. Schneider, J.L.W. Rademaker, F.J. de Bruijn, and L.E. Jackson. 1999. Multiphasic analysis of xanthomonads causing bacterial spot disease on tomato and pepper in the Caribbean and Central America: Evidence for common lineages within and between countries. Phytopathology 89:328-335.

Carlton, W.M., M.L. Gleason, and E.J. Braun. 1994. Effects of pruning on tomato plants supporting epiphytic populations of Clavibacter michiganensis subsp. michiganensis. Plant Dis. 78:742-745.

Conover, R.A. and N.R. Gerhold. 1981. Mixtures of copper and maneb or mancozeb for control of bacterial spot of tomato and their compatibility for control of fungus diseases. Proc. Florida State Hort. Soc. 94:154-156.

Horsfall, J.G. and R.W. Barratt. 1945. An improved grading system for measuring plant disease. Phytopathology 35:655.

Hushon, J.M. 2006. Pesticides in southwest Florida waterways: A report card. Fla. Sci. 69:100-116.

Jeger, M.J. 2004. Analysis of disease progress as a basis for evaluating disease management practices. Annu. Rev. Phytopathol. 42:61-82.

Jones, J.B. 1991. Bacterial spot, p. 27. In: J.B. Jones, J.P. Jones, R.E. Stall and T.A. Zitter (eds.). Compendium of tomato diseases. APS Press, St., Paul, MN. 
Jones, J.B. and J.P. Jones. 1985. The effect of bactericides, tank mixing time, and spray schedule on bacterial leaf spot of tomato. Proc. Florida State Hort. Soc. 98: 244-247.

Jones, J.B., G.H. Lacy, H. Bouzar, R.E. Stall, and N.W. Schaad. 2004. Reclassification of the xanthomonads associated with bacterial spot disease of tomato and pepper. Syst. Appl. Microbiol. 27:755762.

Jones, J.B., L.E. Jackson, B. Balogh, A. Obradovic, F.B. Iriarte, and M.T. Momol. 2007. Bacteriophages for plant disease control. Annu. Rev. Phytopathol. $45: 245-262$.

Jones, J.B., S.S. Woltz, J.P. Jones, and K.L. Portier. 1991. Population dynamics of Xanthomonas campestris pv. vesicatoria on tomato leaflets treated with copper bactericides. Phytopathology 81:714719

Kemble, J.M., J.M. Davis, R.G. Gardner, and D.C. Sanders. 1994. Spacing, root cell volume, and age affect production and economics of compact-growth-habit tomato. HortScience 29:1460-1464.

Louws, F.J., M. Wilson, H.L. Campbell, D.A. Cuppels, J.B. Jones, P.B. Shoemaker, F. Sahin, and S.A. Miller. 2001. Field control of bacterial spot and bacterial speck of tomato using a plant activator. Plant Dis. 85:481-488.

Navarrete, M. and B. Jeannequin. 2000. Effect of frequency of axillary bud pruning on vegetative growth and fruit yield in greenhouse tomato crops. Sci. Hort. 86: 197-210.

Obradovic, A., J.B. Jones, M.T. Momol, B. Balogh, and S.M. Olson. 2004. Man- agement of tomato bacterial spot in the field by foliar applications of bacteriophages and SAR inducers. Plant Dis. 88: 736-740.

Obradovic, A., J.B. Jones, M.T. Momol, S.M. Olson, L.E. Jackson, B. Balogh, K. Guven, and F.B. Iriarte. 2005. Integration of biological control agents and systemic acquired resistance inducers against bacterial spot of tomato. Plant Dis. 89:712-716.

O'Garro, L.W. and E. Charlemagne. 1994. Comparison of bacterial growth and activity of glucanase and chitinase in pepper leaf and flower tissue infected with Xanthomonas campestris pv. vesicatoria. Physiol. Mol. Plant Pathol. 45:181-188.

O'Garro, L.W. and S. Tudor. 1994. Contribution of 4 races of Xanthomonas cam pestris pv. vesicatoria to bacterial spot in Barbados. Plant Dis. 78:88-90.

Olson, S.M., W.M. Stall, M.T. Momol, S.E. Webb, T.G. Taylor, S.A. Smith, E.H Simonne, and E. McAvoy. 2006. Tomato production in Florida, p. 407-426. In: S.M. Olson and E.H. Simonne (eds.). Vegetable production handbook for Florida, 2006-2007. Inst. Food Agr. Sci, Univ. of Florida, Gainesville.

Pernezny, K., L.E. Datnoff, T. Mueller, and J. Collins. 1996. Losses of freshmarket tomato production in Florida due to target spot and bacterial spot and the benefits of protectant fungicides. Plant Dis. 80:559-563.

Pietrzak, U. and D.C. McPhail. 2004 Copper accumulation, distribution and fractionation in vineyard soils of Victoria, Australia. Geoderma 122:151-166.
Pohronezny, K. and R.B. Volin. 1983. The effect of bacterial spot on yield and quality of fresh-market tomatoes. HortScience 18:69-70.

Rhoads, F.M., S.M. Olson, and A. Manning. 1989. Copper toxicity in tomato plants. J. Environ. Qual. 18:195-197.

Rice, P.J., L.L. McConnell, L.P. Heighton, A.M. Sadeghi, A.R. Isensee, J.R. Teasedale, A.A. Abdul-Baki, J.A. Harman-Fetcho, and C.J. Hapeman. 2002. Comparison of copper levels in runoff from fresh-market vegetable production using polyethylene mulch or a vegetative mulch. Environ. Toxicol. Chem. 21:24-30.

Roberts, P.D., M.T. Momol, L. Ritchie, S.M. Olson, J.B. Jones, and B. Balogh. 2008. Evaluation of spray programs containing famoxadone plus cymoxanil, acibenzolar-S-methyl, and Bacillus subtilis compared to copper sprays for management of bacterial spot of tomato. Crop Prot. 27:1519-1526.

Santos, B.M. 2008. Early pruning on 'Florida-47' and 'Sungard' tomato. HortTechnology 18:467-470.

Sargent, S.A., J.K. Brecht, and T. Olczyk. 2005. Handling Florida vegetable series: Round and Roma tomato types. 21 Nov. 2009. <http://edis.ifas.ufl.edu/pdffiles/ $\mathrm{VH} / \mathrm{VH} 07900$.pdf $>$.

Sikes, J. and D.L. Coffey. 1976. Catfacing of tomato fruits as influenced by pruning. HortScience 11:26-27.

U.S. Department of Agriculture. 2010. Vegetables. 4 Apr. 2010. <http://usda. mannlib.cornell.edu/usda/current/Vege/ Vege-04-01-2010.pdf>. 